Malliari, A., Korobili, S. and Zapounidou, S. (2011). Exploring the information seeking behavior of Greek graduate students: A case study set in the University of Macedonia. The International Information \& Library Review, 43(2), pp.79-91. doi:10.1016/j.iilr.2011.04.006

\title{
Exploring the information seeking behavior of Greek graduate students: A case study set in the University of Macedonia
}

\author{
Afrodite Malliari $^{a}$, Stella Korobili $^{\text {a }}$, Sofia Zapounidou ${ }^{b}$
}

${ }^{a}$ Department of Library and Information Systems, Technological Educational Institution of Thessaloniki, P.O. BOX 141, 57400 Sindos, Thessaloniki, Greece, malliari@libd.teithe.gr (A. Malliari), koro@libd.teithe.gr (S. Korobili)

${ }^{\mathrm{b}}$ Aristotle University of Thessaloniki, Library System, Central Library, Thessaloniki, Greece, szapoun@lib.auth.gr

\begin{abstract}
This paper describes a survey designed to determine the information seeking behavior of graduate students at the University of Macedonia (UoM). The survey is a continuation of a previous one undertaken in the Faculties of Philosophy and Engineering at the Aristotle University of Thessaloniki (AUTh). This paper primarily presents results from the UoM survey, but also makes comparisons with the findings from the earlier survey at AUTh. The 254 UoM students responding tend to use the simplest information search techniques with no critical variations between different disciplines. Their information seeking behavior seems to be influenced by their search experience, computer and web experience, perceived ability and frequency of use of esources, and not by specific personal characteristics or attendance at library instruction programs. Graduate students of both universities similar information seeking preferences, with the UoM students using more sophisticated techniques, such as Boolean search and truncation, more often than the AUTh students.
\end{abstract}

\section{Keywords}

Information seeking behavior; Academic libraries; Graduate students; Greece

\section{Introduction}

This paper describes a study that was undertaken to determine the information seeking behavior of graduate students attending the 13 postgraduate programs offered by the University of Macedonia (UoM) in Thessaloniki, Greece. This study is a continuation of a previous study which was undertaken to determine the information seeking behavior of graduate students of ten postgraduate programs offered by the faculties of Philosophy and Engineering at the
Aristotle University of Thessaloniki (AUTh). The factors that played an important role in shaping the information seeking behavior in the previous study were found to be search experience, computer and web experience, perceived ability and frequency of use of e-sources. This survey tried to identify whether UoM graduate students demonstrated different information seeking behavior from AUTh Philosophy and Engineering graduate students. It also attempted to investigate whether other factors than those mentioned above played an important role in shaping their information 
seeking behavior. Therefore, the questionnaire that had been used previously was extended and included other possible factors that might influence the information seeking behavior of young researchers, such as personal characteristics and attendance at library instruction seminars. It is hoped that this survey might provide a deeper understanding of the causes that shape the information seeking behavior of Greek students.

The UoM Library offers programs to both undergraduate and graduate students for the development of library skills. Examining the possible effects on information seeking behavior of the graduate students who have attended a library education program would give a better picture to librarians. Based on the results of both surveys, librarians may be able to develop better information literacy programs focused on the information habits of graduate students.

\section{Literature review}

Information seeking is a "highly subjective process" (Weiler, 2005) influenced by many factors and interactions between them. These factors are related to at least one of the three information seeking behavior core entities: the information need, the environment and the seeker (personal factors) (Marchionini, 1997; Wilson, 1981, 2006). As far as the information need is concerned, some studies have connected information seeking to information need and motivation (Dervin, 1992; Weiler, 2005; Heinström, 2006). Other studies (Byström \& Järvelin, 1995; Vakkari, 1999) have emphasized the interaction between understanding information needs and task complexity. Task complexity and type of task were also found to have "significant main effect on search outcomes as well as on several other search activities" (Kim \& Allen, 2002, p. 115). Many studies have indicated a connection between the type of information needed and the definition of desired information channels and sources, and this has an impact on information systems processes (Barrett, 2005; Callinan, 2005; Cosijn, 2006; Davies, 2007; Johnson et al., 2006; Landry \& Fay, 2006; Leckie, Pettigrew, \& Sylvain, 1996). However, many studies found users acting regardless of their information need with a tendency to bypass complex information channels and advanced techniques (Fast \& Campbell, 2004; George et al., 2006; Kerins, Madden, \& Fulton, 2004; Makani \& WooShue, 2006; Vezzosi, 2009) in favor of 'simpler' web search and search engines such as Google/GoogleScholar (Fast \& Campbell, 2004; George et al., 2006; Griffiths \& Brophy, 2005; Hemminger, Lu, Vaughan, \& Adams, 2007; Haglund \& Olsson, 2008; Jamali \& Asadi, 2010).

The most important entity in information seeking remains the information seeker with his/her key characteristics having an effect upon preferred search strategies and overall seeking performance. These characteristics include demographic, cognitive and psychological variables. Demographic variables and their relationship with information seeking choices and strategies have been studied mostly in terms of age/generation (Weiler, 2005; Haglund \& Olsson, 2008; Hargittai, 2010), gender (Hargittai \& Shafer, 2006; Rowlands \& Nicholas, 2008; Whitmire, 2002) and academic status (Branch, 2003; Banwell \& Coulson, 2004; Barrett, 2005; Callinan, 2005; Chen, 2009; Francis, 2005; Finn \& Johnston, 2004; Fidzani, 1998; George et al., 2006;
Griffiths \& Brophy, 2005; Korobili, Tilikidou, \& Delistavrou, 2006; Liao, Finn, \& Lu, 2007; Patitungkho \& Deshpande, 2005; Rieger, 2009; Rowlands \& Nicholas, 2008; Sadler \& Given, 2007; Vezzosi, 2009; Whitmire, 2002).

In relation to cognitive processes and the academic environment, some studies have found that discipline plays a significant role in information seeking (George et al., 2006; Kerins et al., 2004; Makani \& WooShue, 2006; Nicholas, Clark, Rowlands, \& Jamali, 2009; Whitmire, 2002; Sadler \& Given, 2007; Talja \& Maula, 2003; Urquhart et al., 2005), while others have noticed the existence of significant variations between different institutions (Nicholas, Huntington, \& Jamali, 2007; Nicholas et al., 2009) due to different "faculty models of research behavior" (Barrett, 2005). However, a number of studies also found little or no correlation between discipline and information seeking behavior (Ellis, Cox, \& Hall, 1993; Heinström, 2003; Korobili, Malliari, \& Zapounidou, 2011; Sharifabadi, 1996). Some other factors that have been demonstrated to influence information seeking are domain knowledge (Hölscher \& Strube, 2000; Jenkins, Corritore, \& Wiedenbeck, 2003; Hembrooke, Granka, Gay, \& Liddy, 2005; Marchionini, 1997; Wildemuth, 2004; Zhang, Anghelescu, \& Yuan, 2005; White, Dumais, \& Teevan, 2009), computer and web experience (Aula, 2005; Aula, Jhaveri, \& Kaki, 2005; Eshet-Alkalai \& Chajut, 2009; Hölscher \& Strube, 2000; Hargittai, 2002; Jenkins, Corritore, \& Wiedenbeck, 2003; Korobili et al., 2011; Thatcher, 2008; Williamson, Bernath, Wright, \& Sullivan, 2008), search experience (Chen, 2009; Hsieh-Yee, 1993; Marchionini, 1997; Tsai, 2009; Williamson et al. , 2008) and frequency of use of esources (Griffiths \& Brophy, 2005; Haglund \& Olsson, 2008; George et al., 2006; Korobili et al., 2006). Some studies have revealed the importance of other people (tutors, instructors, colleagues, librarians, friends, etc.) in the information seeking process (Branch, 2003; Barrett, 2005; George et al., 2006; Griffiths \& Brophy, 2005; Patitungkho \& Deshpande, 2005; Vezzosi, 2009). In relation to the influential role of librarians, some studies have indicated the influence of library instruction or other information literacy programs on information seeking behavior (Branch, 2003; Brunton, 2007; Craig \& Corrall, 2007; Kai-Wah Chu \& Law, 2008; Samson, 2010; Tramullas \& Casabon, 2010; Urquhart \& Rowley, 2007).

Attempts have been made to associate information seeking behavior with specific cognitive styles (Ford, Miller, \& Moss, 2005; Kim \& Allen, 2002). Palmer (1991, p. 256) observed that, "Cognitive style represents the manner in which an individual receives, processes and uses information (and) is to be distinguished from more general descriptions of personality and 'individual difference."' Many studies have tried to explore the psychological variables in terms of the personal traits that influence a seeker's behavior, using a variety of psychological theories, models and tools (Amiel \& Sargent, 2004; Blickle, 1996; Heinström, 2000; Heinström, 2003; Heinström, 2005; Landers \& Lounsbury, 2006; Palmer, 1991). A wellstudied variable is the perceived ability to use computers and search the Internet and online information sources (databases and e-journals). This variable, also known as computer and/or internet self-efficacy, has been shown to have a high correlation with information seeking performance and strategies (Brown, Ganesan, \& Challagalla, 
Table 1 Frequency of using different information retrieval activities ( $N Z 254$ ).

\begin{tabular}{|c|c|c|c|c|c|c|}
\hline & $\begin{array}{l}\text { Never } \\
\%\end{array}$ & $\begin{array}{l}1 \mathrm{e} 2 / \\
\text { semester } \\
\%\end{array}$ & $\begin{array}{l}1 \mathrm{e} 2 / \\
\text { trimester } \\
\%\end{array}$ & $\begin{array}{l}1 \mathrm{e} 2 / \\
\text { month } \\
\%\end{array}$ & $\begin{array}{l}1 \mathrm{e} 3 / \\
\text { week } \\
\%\end{array}$ & $\begin{array}{l}\text { Every- } \\
\text { day \% }\end{array}$ \\
\hline Searching the web & & & & 1.6 & 11.5 & 87.0 \\
\hline Searching library web page & 7.5 & 12.2 & 10.2 & 31.1 & 31.5 & 7.5 \\
\hline Searching databases & 24.8 & 15.0 & 17.3 & 24.8 & 14.2 & 3.9 \\
\hline Searching e-journals & 18.1 & 17.7 & 16.5 & 24.4 & 18.9 & 4.3 \\
\hline Browsing library shelves & 12.2 & 16.1 & 26.0 & 35.8 & 8.3 & 1.6 \\
\hline Using personal printed sources & 12.2 & 15.7 & 18.1 & 26.0 & 21.3 & 6.7 \\
\hline Consulting a fellow student & 3.1 & 12.6 & 15.0 & 29.9 & 32.3 & 7.1 \\
\hline Consulting a librarian & 38.2 & 24.8 & 22.4 & 10.2 & 4.3 & \\
\hline Consult professor's recommended reading list & 4.3 & 11.4 & 16.9 & 27.6 & 31.5 & 8.3 \\
\hline Consult the bibliography of an article/a book & 19.7 & 15.7 & 13.8 & 22.8 & 20.5 & 7.5 \\
\hline Alerting services offered by scientific databases & 55.1 & 9.8 & 11.8 & 9.4 & 7.1 & 6.7 \\
\hline
\end{tabular}

2001; Hargittai \& Shafer, 2006; Kim, 2009; Ren, 2000; Tella, 2009; Tsai \& Tsai, 2003; Waldman, 2003).

\section{Research objectives}

Addressed to UoM graduate students, the purpose of the present study was to identify whether discipline, frequency of use, experience in computers and e-sources, perceived ability and attending library programs affect respondents' information seeking behavior. More specifically, this study aimed to:

- examine whether information seeking behavior of graduate students varied across different disciplines;

- explore the information seeking behavior of graduate students who have attended library instruction programs;

- record whether information seeking behavior varied across different personal traits;

- investigate whether frequency of use, perceived ability and computer/Internet experience affect the information seeking behavior of graduate students.

\section{Methodology}

The survey was addressed to students on all 13 UoM postgraduate programs and it was carried out during the winter and spring semester of the academic period $2009 \mathrm{e} 2010$. The instrument was a specially designed, structured questionnaire, which was available online through the
SurveyMonkey platform. Students were invited to complete the survey questionnaire by an email sent to them by their postgraduate program secretary. Only one postgraduate program director refused to cooperate with the mailing process and so printed copies of the survey questionnaire were distributed to the students from this program after class. The postgraduate programs were grouped in four different domains according to their disciplines: political studies, economic studies, management studies and informatics. The population comprised approximately 977 graduate students and the response rate obtained was approximately 26 per cent. The procedure produced 254 fully answered and therefore usable questionnaires.

The first part of the questionnaire contained the following demographic and situational variables about the respondents: gender, age, program in which they were enrolled, level of foreign language, and attendance on any library instruction program (See Appendix). The second part of the questionnaire contained questions referring to a) experience of computers and e-sources, b) the frequency of use of resources, which was a composite measure based on eleven items, each measured on a five-point frequency scale, where "Never" counted as zero, and c) the most commonly adopted practices when starting a search process. The third part of the questionnaire consisted of two questions which referred to the factors that influenced the conduct of a search and the personal traits that participants developed during it. The personal traits were measured using the Ten-Item-Personality Inventory (TIPI) (Gosling, Rentfrow, \& Swann, 2003), a short measure of the 'Big-Five' personality factors. The fourth part of the

Table 2 Factors affecting search process in descending order ( $N$ Z 254).

\begin{tabular}{lll}
\hline & Mean & Std. Deviation \\
\hline Personal interest in the topic & 2.82 & 1.144 \\
Ease of access concerning time (e.g. more/less time for locating the source, etc) & 2.68 & 1.233 \\
Convenience of access (e.g. home, office, lab, library, etc) & 2.55 & 1.355 \\
Ease of using the source (e.g. required simple search techniques) & 2.47 & 1.262 \\
Previous knowledge of the topic & 2.34 & 1.106 \\
Very specialized topic of research & 2.04 & 1.126 \\
Guidance of the professor for the relevant sources & 2.02 & 1.109 \\
Cost (if any) & 1.99 & 1.283 \\
\hline
\end{tabular}


Table 3 Personal characteristics ( $N$ Z 254).

\begin{tabular}{lcc}
\hline & Mean Std. Deviation \\
\hline Critical, quarrelsome & 3.93 & 0.634 \\
Sympathetic, warm & 3.92 & 0.737 \\
Dependable, self-disciplined & 3.81 & 0.765 \\
Open to new experiences, complex & 3.76 & 0.871 \\
Calm, emotionally stable & 3.58 & 0.867 \\
Extraverted, enthusiastic & 3.49 & 0.900 \\
Anxious, easily upset & 3.10 & 1.125 \\
Conventional, uncreative & 2.57 & 0.958 \\
Reserved, quiet & 2.31 & 0.993 \\
Disorganized, careless & 2.02 & 0.996 \\
\hline
\end{tabular}

questionnaire consisted of questions about the information retrieval techniques users were engaged in, the modifications they made, and the way they evaluated search results with regard to relevance. The last question asked about the frequency of certain relevance-related activities employed during information retrieval.

Descriptive statistical indices, including frequencies, means and standard deviations, were used to present the data. Only results where the observed significance level ( $p$-value) was found to be statistically significant (at the 0.01 level) are reported and discussed. Multiple Linear Regressions were also applied to identify which variables might predict information seeking behavior.

\section{Findings}

\section{Profile of UoM graduate students}

Descriptive statistics indicated that $48 \%$ of the sample was women while $52 \%$ were men. Their ages ranged from 22 to 47 years old ( $M Z 28.15)$. $43 \%$ of respondents came from the informatics domain, $24 \%$ from political studies, $22 \%$ from management studies and $11 \%$ from economic studies.

Students declared that they delivered 1.64 assignments per course and $89 \%$ of them claimed that they had a very good or excellent command of English. 38\% of the respondents had attended a user education program offered by the University Library, either at the undergraduate or graduate level, while $62 \%$ had never attended such a program, either because they did not know about it or because they thought it would be uninteresting or unnecessary. The vast majority claimed to have computer
Table 5 Use of techniques for modifying the search strategy in descending order of importance.

\begin{tabular}{lll}
\hline & Mean & Std. deviation \\
\hline Change the keywords & 3.30 & 1.058 \\
Choosing another source & 2.48 & 1.263 \\
Changing search strategy & 1.72 & 1.385 \\
\hline
\end{tabular}

experience and Internet experience (92\% and 82\% respectively) of more than five years, while only $29 \%$ and $38 \%$ claimed that they had experience in searching databases or e-journals for $3 \mathrm{e} 5$ years and more than 5 years, respectively. As for their perceived ability, 54\% considered themselves experts in searching the web, while $61 \%$ perceived themselves as competent and proficient in searching scientific databases and/or electronic journals.

With reference to specific information retrieval activities, as might have been anticipated, searching the web every day, was the most common method $(87 \%)$ used by graduate students to discover information. It should be noted that $38 \%$ had never asked help from a librarian, while $25 \%$ had asked only $1 \mathrm{e} 3$ times in six months. For details about each item included, see Table 1. The above results were confirmed by the responses to the next question, which referred to their most common practice when starting an information search; searching search engines was the most popular practice (84\%), followed by consulting a professor (63\%), searching the library's web page (60\%), using personal printed sources (47\%), consulting a fellow-student and consulting the bibliography of an article/a book (47\%), searching e-journals (43\%), browsing library shelves (41\%), searching databases (32\%) and finally consulting a librarian (11\%).

Students reported how a number of factors affected them while conducting a search. The factor that affected them most was personal interest in the topic and the one that affected them least was the cost (if any). For details of each factor see Table 2.

Taking into consideration the extended literature review concerning the effect of personal characteristics on information seeking behavior, students were also asked the extent to which they manifested each one of the TIPI personal characteristics when searching for and retrieving information. They considered themselves critical $(M Z$ 3.93), sympathetic ( $M Z$ 3.92) and self disciplined $(M Z$ 3.81) when searching for and retrieving information from sources. Table 3 gives the general picture of respondents' beliefs about themselves.

Table 4 Use of search techniques ( $N$ Z 254).

\begin{tabular}{lccccc} 
& Never & Seldom & Often & Quite often & Very often \\
\hline One Keyword & 5.5 & 2.4 & 9.8 & 24.4 & 57.9 \\
More than one keyword & 4.7 & 0.8 & 7.1 & 24 & 63.4 \\
Phrase & 9.1 & 13.8 & 22.5 & 20.6 & 34 \\
Boolean operators & 29.1 & 29.9 & 16.9 & 10.6 & 13.4 \\
Proximity operators & 49.2 & 33.5 & 9.4 & 3.5 & 4.3 \\
Truncation & 42.1 & 29.1 & 11 & 19.3 & 9.4 \\
Searching within results & 18.5 & 19.3 & 31.1 & 18.5 & 8.3 \\
Finding similar results & 17.3 & 24.8 & 19.7 & 15.4 & 5.5 \\
Searching within time range & 29.5 & 29.9 & & \\
\hline
\end{tabular}


Table 6 Evaluation criteria in descending order of importance.

\begin{tabular}{lll}
\hline & Mpan & C+d neviatinn \\
\hline The title of the source & 2.66 & 1.123 \\
Objectivity of the source & 2.54 & 1.265 \\
Date of publication & 2.52 & 1.330 \\
The abstract of the source & 2.51 & 1.221 \\
The title of the periodical & 2.47 & 1.151 \\
Descriptors & 2.16 & 1.176 \\
The source is included in the & 2.09 & 1.196 \\
$\quad$ bibliography of a relevant & & \\
$\quad$ book or article & & \\
$\quad$ The author's name & 2.01 & 1.305 \\
The source is reviewed & 1.70 & 1.333 \\
\hline
\end{tabular}

Information seeking behavior of UoM graduate students

A great number $(63 \%)$ of the graduate students used more than one keyword very often in their effort to obtain relevant information when they had complex information needs, while $58 \%$ used one keyword very often (see Table 4).

The use of techniques for modifying the search strategy, if initial results were not satisfactory, is not surprising.

Respondents mainly chose to change the keywords $(M$

Z3.30), followed by choosing another source (MZ2.48) and changing the search strategy ( $M Z 1.72$ ) (see Table 5).

As for the criteria respondents used to decide whether the results were relevant or not, they mostly considered the title of the source ( $M Z 2.66$ ), followed by objectivity of the source $(M Z 2.54)$, date of publication $(M Z 2.52)$, the abstract of the source $(M Z 2.51)$, the title of the periodical ( $M Z 2.47)$, and the descriptors ( $M Z 2.16)$. Three other options were used as criteria for relevance, namely whether the source is included in the bibliography of a relevant book or article, the author's name and whether the source is reviewed ( $M Z 2.09, M Z 2.01$, and $M Z 1.70$, respectively). Almost half the respondents (48\%) used one of the criteria mentioned above quite of ten or very often, while $26 \%$ have never or seldom used any of the criteria (see Table 6).
Effect of background characteristics on information seeking behavior

The behavior of students in the different postgraduate programs was compared to see whether there were any differences. The programs were grouped in the four scientific domains mentioned above. It was found that there were no statistically significant relationships between different domains and information seeking behavior. In other words, behavior was consistent across groups in terms of information seeking behavior and using search techniques, modifying the initial statement, evaluating available sources and identifying the relevance of sources. On the other hand, significant relationships were

found among the four scientific domains and the most common practice used for starting searching for relevant information, especially between those in informatics and those in economics and management. In particular, the greatest percentage (39\%) of students who started their search by searching the library web page belonged to the informatics domain, while $35 \%$ of political studies students, $13 \%$ of economic studies students and $13 \%$ of management studies students started their search in this way. From those who started their search by searching e-journals $42 \%$ came from political studies and $35 \%$ from informatics. Table 7 contains the percentage of using each technique in relation to each one of the four scientific domains.

In relation to gender, there are no statistically significant relationships between gender and the responses dealing with information seeking behavior. In other words, men and women in the present study seem to have the same information seeking behavior.

\section{Effect of attending library instruction programs on information seeking behavior}

It was also found that there were statistically significant relationships between attending a library education program and the variables concerning information seeking behavior (using search techniques, modifying the initial statement and evaluating available sources). In particular, statistically

Table 7 The most common practice used for starting a search and scientific domain (N Z 254).

\begin{tabular}{|c|c|c|c|c|}
\hline & Informatics \% & Political studies \% & Economic studies \% & Management studies \% \\
\hline $\begin{array}{l}\text { Searching the library } \\
\text { web page }\end{array}$ & 38.7 & 35.3 & 13.3 & 12.7 \\
\hline Searching e-journals & 34.9 & 42.2 & 12.8 & 10.1 \\
\hline Browsing library shelves & 40.4 & 34.6 & 13.5 & 11.5 \\
\hline $\begin{array}{l}\text { Using personal printed } \\
\text { sources }\end{array}$ & 38.7 & 32.8 & 16.8 & 11.8 \\
\hline $\begin{array}{l}\text { Consulting a fellow } \\
\text { student }\end{array}$ & 40.7 & 25.4 & 17.8 & 16.1 \\
\hline $\begin{array}{l}\text { Consulting professor's } \\
\text { recommended reading } \\
\text { list }\end{array}$ & 37.9 & 32.9 & 15.5 & 13.7 \\
\hline $\begin{array}{l}\text { Consulting the } \\
\text { bibliography of an } \\
\text { article/a book }\end{array}$ & 36.4 & 42.4 & 12.7 & 8.5 \\
\hline
\end{tabular}

The bold percentages are the greatest in each item. 
Table 8 Attending library instruction program and information seeking behavior.

\begin{tabular}{|c|c|c|c|c|c|c|c|}
\hline Search techniques & & Never & Seldom & Often & Quite often & Very often & $p$ \\
\hline & Boolean operators & $16.5 \%$ & $33.0 \%$ & $18.6 \%$ & $11.3 \%$ & $20.6 \%$ & 0.004 \\
\hline & Proximity operators & $36.1 \%$ & $36.1 \%$ & $13.4 \%$ & $7.2 \%$ & $7.2 \%$ & 0.002 \\
\hline & Truncation & $28.9 \%$ & $27.8 \%$ & $13.4 \%$ & $13.4 \%$ & $16.5 \%$ & 0.000 \\
\hline & Searching within results & $6.2 \%$ & $22.7 \%$ & $36.1 \%$ & $22.7 \%$ & $12.4 \%$ & 0.003 \\
\hline & Finding similar results & $5.2 \%$ & $29.9 \%$ & $38.1 \%$ & $19.6 \%$ & $7.2 \%$ & 0.001 \\
\hline & $\begin{array}{l}\text { Searching within time } \\
\text { range }\end{array}$ & $19.6 \%$ & $30.9 \%$ & $29.9 \%$ & $13.4 \%$ & $6.2 \%$ & 0.007 \\
\hline \multirow{4}{*}{$\begin{array}{l}\text { Modification } \\
\text { techniques }\end{array}$} & & Never & Seldom & Often & Quite often & Very often & $p$ \\
\hline & $\begin{array}{l}\text { Choosing different } \\
\text { keyword/keywords }\end{array}$ & $0.0 \%$ & $1.0 \%$ & $6.2 \%$ & $28.9 \%$ & $63.9 \%$ & 0.015 \\
\hline & $\begin{array}{l}\text { Choosing different } \\
\text { source }\end{array}$ & $1.0 \%$ & $11.3 \%$ & $20.6 \%$ & $28.9 \%$ & $38.1 \%$ & 0.000 \\
\hline & Changing strategy & $16.5 \%$ & $19.6 \%$ & $22.7 \%$ & $17.5 \%$ & $23.7 \%$ & 0.009 \\
\hline \multirow[t]{7}{*}{ Evaluation Criteria } & & Not at all & Little & Enough & Much & Very much & $p$ \\
\hline & Name of the author & $6.2 \%$ & $16.5 \%$ & $34.0 \%$ & $22.7 \%$ & $20.6 \%$ & 0.006 \\
\hline & Title of the journal & $3.1 \%$ & $5.2 \%$ & $25.8 \%$ & $42.3 \%$ & $23.7 \%$ & 0.008 \\
\hline & Descriptors & $5.2 \%$ & $9.3 \%$ & $34.0 \%$ & $38.1 \%$ & $13.4 \%$ & 0.010 \\
\hline & Abstract of the source & $2.1 \%$ & $7.2 \%$ & $19.6 \%$ & $38.1 \%$ & $33.0 \%$ & 0.001 \\
\hline & The source is reviewed & $15.5 \%$ & $25.8 \%$ & $18.6 \%$ & $18.6 \%$ & $21.6 \%$ & 0.008 \\
\hline & Objectivity of the source & $0.0 \%$ & $6.2 \%$ & $22.7 \%$ & $36.1 \%$ & $35.1 \%$ & 0.000 \\
\hline
\end{tabular}

significant relationships were found between attending a library instruction program and search techniques, such as Boolean operators, proximity operators, truncation, searching within results, finding similar results, and searching within time range. Among those who had attended library instruction programs $32 \%$ have used Boolean operators quite often and very often, $14 \%$ proximity operators, $30 \%$ truncation, $35 \%$ searching within results, $27 \%$ finding similar results and $20 \%$ searching within time range (see Table 8).

A statistically significant relationship was also observed between attending a library instruction program and modification techniques, such as choosing a different keyword or keywords. Among those who had have attended library instruction programs, $93 \%$ has modified the initial statement quite often or very often, $67 \%$ had chosen a different source and $41 \%$ changed search strategy (see Table 8 ).

Finally, significant relationships were found between attending a library instruction program and the criteria used for evaluating sources. There was a statistically significant relationship with many criteria, such as the name of the author, title of the journal, descriptors, abstract of the source, the source is reviewed, and objectivity of the source. Among those who had attended library instruction programs, $43 \%$ considered that the name of the author contributed to effective evaluation much or very much, while $66 \%$ considered the title of the journal, $52 \%$ descriptors, $71 \%$ abstract of the source, $40 \%$ source is reviewed and $71 \%$ objectivity of the source (see Table 8 ).

\section{Effect of personal traits on information seeking behavior}

The correlations between information seeking behavior and certain personal characteristics were examined. Given the small numbers in each cell, these data must be interpreted with caution, and broad generalizations should not be made from this single case study. After determining the reliability

Table 9 Correlations of personal trait variables with search and modification techniques and evaluation criteria.

\begin{tabular}{lccc}
\hline & Search techniques & Modification techniques & Evaluation Criteria \\
\hline $\begin{array}{l}\text { Being critical and } \\
\text { quarrelsome }\end{array}$ & $0.151^{*}$ & 0.099 & $0.198^{* *}$ \\
$\begin{array}{l}\text { Being reserved and quiet } \\
\begin{array}{l}\text { Being disorganized, } \\
\text { careless }\end{array}\end{array}$ & -0.116 & -0.097 & $\mathrm{LO} 0.251^{* *}$ \\
$\begin{array}{l}\text { Being conventional and } \\
\text { uncreative }\end{array}$ & -0.106 & $\mathrm{~L} 0.138^{*}$ & $\mathrm{LO} .128^{*}$ \\
\hline
\end{tabular}

${ }^{* *}$ Correlation is significant at the 0.01 level (2-tailed).

*Correlation is significant at the 0.05 level (2-tailed).

The statistically significant are presented in bold. 
of the scales on which participants' use of search techniques (a $Z$ 0.819), modification techniques (a $Z$ 0.743) and evaluation criteria (a $Z$ 0.843) were measured, new variables were created for the mean scores of the items of each scale. Pearson correlations were performed and indicated positive relationships between being critical and quarrelsome and both search and evaluation techniques. Pearson correlation coefficients also indicated significant correlations between being reserved and quiet and evaluation of retrieved sources, between being conventional and uncreative and both search and modification techniques, and also between being disorganized and careless and both modification and evaluation techniques. As shown in Table 9, being reserved and quiet correlated negatively with evaluation of retrieved sources, being conventional and uncreative correlated negatively with search techniques and modification of techniques, and being disorganized, careless correlated negatively with modification techniques and evaluation criteria.

\section{Discussion}

In order to identify and retrieve relevant information most graduate students used the simplest techniques. These results are consistent with the findings of other studies (Fast \& Campbell, 2004; George et al., 2006; Kerins et al., 2004; Makani \& WooShue, 2006; Vezzosi, 2009). It is also interesting to note that, compared with the results of a previous study in the Faculties of Philosophy and Engineering of Aristotle University of Thessaloniki (Korobili et al., 2011), the same pattern in using the techniques for obtaining relevant information can be seen, but the percentages using Boolean operators and truncation (more sophisticated techniques) are greater in UoM graduate students. In addition, a great percentage, more than half of the respondents, considered themselves experts in searching the web, and competent and proficient in searching scientific databases and/or electronic journals. In spite of their perceived experience, the most frequently used technique for complex information needs and searches was more than one keyword. As for the criteria they used to evaluate sources, title of the source and not descriptors or the summary appeared at the top of their preferences. Objectivity of the source and date of publication played a major role for the respondents, because they were mainly are dealing with the web and not databases or e-journals.

The present study confirmed the results of a previous study about discipline and information seeking behavior among Greek graduate students of the Aristotle University of Thessaloniki (Korobili et al., 2011). In both studies it was found that the information seeking behavior of respondents seemed not to be affected by their discipline, which is in agreement with some earlier studies (Ellis et al., 1993; Heinström, 2003; Sharifabadi, 1996) but contrary to some other significant studies reported in the literature (George et al., 2006; Kerins et al., 2004; Makani \& WooShue, 2006; Sadler \& Given, 2007; Nicholas et al., 2009; Talja \& Maula, 2003; Urquhart et al., 2005; Whitmire, 2002). However, in this study statistically significant relationships were found between disciplines and students' preferences for initiating a search for relevant information. Students from political studies prefer e-journals, a more sophisticated way to search for information. In all other techniques students from informatics had higher percentages, probably because they were almost half of the respondents (43\%).

The information seeking behavior of UoM students seems not to be affected by their gender. This result contradicts the findings of Whitmire (2002), Hargittai and Shafer (2006) and Rowlands and Nicholas (2008).

Other variables, such as search experience, computer and web experience, perceived ability and frequency of use of esources played an important role in shaping information seeking behavior, and this is in line with the findings of earlier studies reported in the literature (Aula, 2005; Aula et al., 2005; Chen, 2009; Eshet-Alkalai \& Chajut, 2009; Griffiths \& Brophy, 2005; George et al., 2006; Haglund \& Olsson, 2008; Hsieh-Yee, 1993; Hölscher \& Strube, 2000; Hargittai, 2002; Jenkins et al., 2003; Korobili et al., 2006; Korobili et al., 2011; Marchionini, 1997; Thatcher, 2008; Tsai, 2009; Williamson et al., 2008).

It seems that library instruction programs did not work effectively, as the students who had attended such programs were not very likely to employ more sophisticated techniques, and fewer than a third of them made use of advanced search techniques, although further study with a larger group is needed. As for the modification techniques, students who had attended library instruction programs seemed to handle them much better, since a great percentage stated they knew how to modify searches effectively. These results may be

accidental, and not reflective of the efficacy of library instruction programs. One may also suppose that this may due to their critical thinking. However, having in mind the whole picture of respondents' information literacy skills, the way they used information and evaluated it did not indicate a

high level of skill. Therefore, the results of the present study are in conflict with many results reported in the relevant literature (Branch, 2003; Brunton, 2007; Craig \& Corrall, 2007; Kai-Wah Chu \& Law, 2008; Samson, 2010; Tramullas \& Casabon, 2010; Urquhart \& Rowley, 2007). In addition, more than half of the students claimed that they had not attended a library instruction program (62\%) and also that they had

never or very seldom consulted a librarian $(63 \%)$. This conflict may be a result of the small sample size, and further research is needed. It could be that the UoM library needs a better marketing strategy towards graduate students who are a difficult target group, because they generally have little time for extra educational activities, such as a library instruction program, and their studies last for one (full-time) or two (part-time) years at most. Also, students often estimate their search competencies to be higher than they are. In this exploratory study, personal traits were not found to be

a significant influential factor on the variables concerning information seeking behavior, in contrast to the findings of

Heinström (2006), Wilson (2006) and Blickle (1996). This finding in our study might be attributed to the fact that the

Greek translations of most of the variables were not well understood by the respondents, and to the fact that students identified their own personal characteristics, which may not be an accurate reflection of the actual characteristics.

\section{Implications and further research}

In this article we have reported the results of a small case study of the information seeking behavior of a sample of UoM 
graduate students, in which it was found that the majority of students responding to the survey do not use any sophisticated techniques for retrieving relevant information. It was also found that gender, discipline, personal traits and library instruction programs did not play a significant role. On the other hand, search experience, computer and web experience, perceived ability and frequency of use of e-sources played an important role in shaping information seeking behavior. These results cannot be generalized beyond the present setting, however, and it is necessary to conduct further studies and make comparisons with a larger sample and with graduate students from other disciplines and other universities. Comparative studies with other universities may reveal differences in information seeking based on different academic, environment or, more specifically, different tutors or librarians responsible for the information literacy/bibliographic instruction programs. Moreover, qualitative research should be used to supplement the quantitative analysis in order to help librarians better understand the information seeking behavior of graduate students and design effective information literacy programs that address their needs and information seeking preferences, in cooperation with the academic faculty. It is widely accepted that information literacy programs are important for the educational process, but such programs should be informed by research that examines their impact in detail.

\section{Appendix}

Information seeking behavior questionnaire

1. Gender:
a. Male $\square$
b. Female $\square$

2. Age:

3. Postgraduate course:

\begin{tabular}{|l|l|}
\hline Master in Economics & \\
\hline Master in Business Administration & \\
\hline Master in Business Administration (executive) & \\
\hline Master in Information Systems & \\
\hline Master in Applied Informatics & \\
\hline Master in Accounting \& Finance & \\
\hline Master in Accounting \& Finance (executive) & \\
\hline $\begin{array}{l}\text { MA in the Politics and Economics of Contemporary Eastern and } \\
\text { Southeastern Europe }\end{array}$ & \\
\hline Master in Educational \& Social Policy & \\
\hline Master in International Studies & \\
\hline Master in European Youth Policy & \\
\hline Other (please specify) & \\
\hline
\end{tabular}

4. Semester:

5. Level of competency in foreign languages:

\begin{tabular}{|l|l|l|l|l|l|}
\cline { 2 - 5 } \multicolumn{1}{c|}{} & None & Average & Good & $\begin{array}{c}\text { Very } \\
\text { good }\end{array}$ & $\begin{array}{c}\text { Excelle } \\
\text { nt }\end{array}$ \\
\hline English & & & & & \\
\hline French & & & & & \\
\hline German & & & & & \\
\hline Italian & & & & & \\
\hline Other (please specify) & & & & & \\
\hline
\end{tabular}

6. During your postgraduate studies how many assignments, on average, that require bibliographic research do you have in each course? 
7. Have you ever attended one or more UoM Library bibliographic instruction/information literacy programs?

\begin{tabular}{|l|l|}
\hline Yes, on undergraduate level. & \\
\hline Yes, on postgraduate level. & \\
\hline Yes, on both undergraduate and postgraduate levels. & \\
\hline No. I didn't think that would be of interest or helpful to me. & \\
\hline No. I didn't know the existence of such programs. & \\
\hline
\end{tabular}

8. How long do you use the following?:

\begin{tabular}{|l|l|l|l|l|l|}
\cline { 2 - 5 } \multicolumn{1}{c|}{} & None & $<1$ year & $1-2$ years & $3-5$ years & $>5$ years \\
\hline persomputers & & & & & \\
\hline $\begin{array}{l}\text { Scientific Databases and/or } \\
\text { electronic journals }\end{array}$ & & & & & \\
\hline
\end{tabular}

9. How much experienced do you consider yourself while searching the following information sources?

\begin{tabular}{|l|c|c|c|c|c|}
\hline \multicolumn{1}{l|}{} & Beginner & $\begin{array}{c}\text { Advanced } \\
\text { Beginner }\end{array}$ & Competent & Proficient & Expert \\
\cline { 2 - 6 } & 1 & 2 & 3 & 4 & 5 \\
\hline $\begin{array}{l}\text { Scientific databases and/or electronic } \\
\text { journals }\end{array}$ & & & & & \\
\hline
\end{tabular}

10. How often do you use each one of the following information seeking activities:

\begin{tabular}{|c|c|c|c|c|c|c|}
\hline & \\
\hline & Never & $\begin{array}{l}1-2 \text { times/ } \\
\text { semester }\end{array}$ & $\begin{array}{l}\text { 1-2times/ } \\
\text { trimester }\end{array}$ & $\begin{array}{l}\text { 1-2 times/ } \\
\text { month }\end{array}$ & 1-3 times/ & Daily \\
\hline \multirow{2}{*}{\multicolumn{7}{|c|}{$\begin{array}{l}\text { Search WWW search engines, e g. Google } \\
\text { Search Library's website le.g. Library }\end{array}$}} \\
\hline & & & & & & \\
\hline \multicolumn{7}{|l|}{$\begin{array}{l}\text { Catalog, Journals' Catalog, etc.) } \\
\text { Search databases (e.g. Web of Science, } \\
\text { Scopus, Web of Science, Scopus, ERIC, } \\
\text { EconLit, CSA, etc.) }\end{array}$} \\
\hline \multicolumn{7}{|l|}{$\begin{array}{l}\text { Search electronic journals (e.g. HEAL-Link } \\
\text { and/or Library's subscriptions, etc.) }\end{array}$} \\
\hline \multicolumn{7}{|l|}{\begin{tabular}{|l} 
Shelf browsing (e.g. printed books, \\
journals,ners, nots
\end{tabular}} \\
\hline \multicolumn{7}{|l|}{ Search personal library at home/office } \\
\hline \multicolumn{7}{|l|}{ Consult a colleague } \\
\hline \multicolumn{7}{|l|}{ Consult a librarian } \\
\hline \multicolumn{7}{|l|}{$\begin{array}{l}\text { Consult professor's recommended reading } \\
\text { list/bibliography }\end{array}$} \\
\hline \multicolumn{7}{|l|}{$\begin{array}{l}\text { Consult the references' list at the end of } \\
\text { articles and/or books }\end{array}$} \\
\hline \multicolumn{7}{|l|}{$\begin{array}{l}\text { Alerting services (Email alerts, saved } \\
\text { searches alerts, etc) offered by scientific } \\
\end{array}$} \\
\hline databases & & & & & & \\
\hline
\end{tabular}

11. Which information seeking activity/-ies do you use when STARTING a bibliographic research?

\begin{tabular}{|c|c|c|}
\hline & YES & NO \\
\hline Search WWW search engines, e.g. Google & & \\
\hline Search Library's website (e.g. Library Catalog, Journals' Catalog, etc.) & & \\
\hline $\begin{array}{l}\text { Search databases (e.g. Web of Science, Scopus, Web of Science, Scopus, ERIC, } \\
\text { EconLit, CSA, etc.) }\end{array}$ & & \\
\hline Search electronic journals (e.g. HEAL-Link and/or Library's subscriptions, etc.) & & \\
\hline Shelf browsing (e.g. printed books, journals, newspapers, etc.) & & \\
\hline 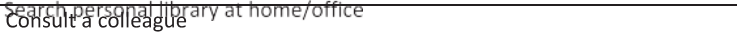 & & \\
\hline Consult a librarian & & \\
\hline Consult professor's recommended reading $\mid i s t /$ bibliography & & \\
\hline $\begin{array}{l}\text { Consult the references' list at the end of articles and/or books } \\
\text { Alerting services (Email alerts, saved searches alerts, etc) offered by scientific }\end{array}$ & & \\
\hline Dthera(palease specify) & & \\
\hline
\end{tabular}


12. How much do the following factors affect you when conducting a bibliographic research?

\begin{tabular}{|c|c|c|c|c|c|}
\hline & Never & Rarely & Often & $\begin{array}{l}\text { Quite } \\
\text { often }\end{array}$ & $\begin{array}{l}\text { Very } \\
\text { often }\end{array}$ \\
\hline \multicolumn{6}{|l|}{ Cost (if applicable) } \\
\hline \multicolumn{6}{|c|}{$\begin{array}{l}\text { Ease of access - place (e.g. home, office, lab, library, } \\
\text { etc.) }\end{array}$} \\
\hline \multicolumn{6}{|l|}{$\begin{array}{l}\text { Ease of time (e.g. much/little time for finding an } \\
\text { information source) }\end{array}$} \\
\hline \multicolumn{6}{|l|}{$\begin{array}{l}\text { Ease of use, (e.g. simple information seeking } \\
\text { techniques required for accessing required } \\
\text { information material) }\end{array}$} \\
\hline \multicolumn{6}{|l|}{ Personal interest for the subject of search } \\
\hline \multicolumn{6}{|l|}{ Pre-existing knowledge of subject } \\
\hline \multicolumn{6}{|l|}{ Very specialised subject for search } \\
\hline \multicolumn{6}{|l|}{$\begin{array}{l}\text { The research will be executed in a source } \\
\text { predetermined/proposed from the professor }\end{array}$} \\
\hline Other (please specify) & & & & & \\
\hline
\end{tabular}

13. How would you describe yourself (which personal traits apply to you) when searching and retrieving information?

\begin{tabular}{|c|c|c|c|c|c|}
\hline & $\begin{array}{c}\text { Strongly } \\
\text { Disagree } \\
1\end{array}$ & $\begin{array}{c}\text { Disagree } \\
2\end{array}$ & $\begin{array}{c}\text { Neither Agree/ } \\
\text { Nor Disagree } \\
3\end{array}$ & $\begin{array}{c}\text { Agree } \\
4\end{array}$ & $\begin{array}{l}\text { Strongly } \\
\text { Agree } \\
5\end{array}$ \\
\hline \multicolumn{6}{|l|}{ Extraverted, enthusiastic. } \\
\hline \multicolumn{6}{|l|}{ Critical, quarrelsome. } \\
\hline \multicolumn{6}{|l|}{ Dependable, self-disciplined. } \\
\hline \multicolumn{6}{|l|}{ Anxious, easily upset. } \\
\hline \multicolumn{6}{|c|}{ Open to new experiences, complex. } \\
\hline \multicolumn{6}{|l|}{ Reserved, quiet. } \\
\hline \multicolumn{6}{|l|}{ Sympathetic, warm. } \\
\hline \multicolumn{6}{|l|}{ Disorganized, careless. } \\
\hline \multicolumn{6}{|l|}{ Calm, emotionally stable. } \\
\hline Conventional, uncreative. & & & & & \\
\hline
\end{tabular}

14. For searching and retrieving relevant results (that is to say relative and useful) you make use of search techniques such as:

\begin{tabular}{|l|l|l|l|l|l|}
\cline { 3 - 5 } \multicolumn{1}{c|}{} & Never & Rarely & Often & $\begin{array}{c}\text { Quite } \\
\text { often }\end{array}$ & $\begin{array}{c}\text { Very } \\
\text { often }\end{array}$ \\
\hline One keyword & & & & & \\
\hline More than one keywords & & & & & \\
\hline A phrase (using quotation marks) & & & & & \\
\hline Boolean operators (AND - OR - NOT) & & & & & \\
\hline $\begin{array}{l}\text { Proximity operators (e.g. Greenhouse NEAR } \\
\text { Effect) }\end{array}$ & & & & & \\
\hline Truncation (e.g. $_{\text {Search within results }}^{*}$ ) & & & & & \\
\hline $\begin{array}{l}\text { Find similar results } \\
\text { Search within a spesific date range } \\
\text { Other (please specify) }\end{array}$ & & & & & \\
\hline
\end{tabular}

15. In case your initial search does not return satisfactory results, how do you modify your search strategy?

\begin{tabular}{|l|l|l|l|l|l|}
\cline { 2 - 6 } \multicolumn{1}{l|}{} & Never & Rarely & Often & $\begin{array}{c}\text { Quite } \\
\text { often }\end{array}$ & $\begin{array}{c}\text { Very } \\
\text { often }\end{array}$ \\
\hline I choose different keyword/keywords & & & & & \\
\hline I choose different information source (e.g. & & & & & \\
\hline $\begin{array}{l}\text { search engine, database, journal provider) } \\
\text { I change search technique (e.g. I use Boolean } \\
\text { operators, truncation, search of phrase instead }\end{array}$ & & & & & \\
\hline $\begin{array}{l}\text { of keywords, etc.) } \\
\text { I suppose that there are no satisfactory results }\end{array}$ & & & & & \\
\hline and stop the search process & & & & & \\
\hline
\end{tabular}

Other (please specify) 
16. How much do the following factors affect you in evaluating the quality of an information resource?

\begin{tabular}{|l|l|l|l|l|l|}
\cline { 2 - 5 } \multicolumn{1}{c|}{} & $\begin{array}{c}\text { Not at } \\
\text { all }\end{array}$ & Little & Enough & $\begin{array}{c}\text { Quite } \\
\text { enough }\end{array}$ & $\begin{array}{c}\text { Very } \\
\text { much }\end{array}$ \\
\hline Name of the author & & & & & \\
\hline Resource's title (e.g. title of an article) & & & & & \\
\hline Journal's title & & & & & \\
\hline Thematic descriptors & & & & & \\
\hline Abstract & & & & & \\
\hline $\begin{array}{l}\text { Other authors' views for the } \\
\text { resource/article, etc. }\end{array}$ & & & & & \\
\hline $\begin{array}{l}\text { If it is included in other articles' (relevant to } \\
\text { you information need) references list }\end{array}$ & & & & & \\
\hline Resource's objectivity & & & & & \\
\hline $\begin{array}{l}\text { Time of publication (older or recent } \\
\text { resources) }\end{array}$ & & & & & \\
\hline Other (please specify) & & & & \\
\hline
\end{tabular}

17. Relevant results: How often do the following situations apply to you?

\begin{tabular}{|l|l|l|l|l|l|}
\cline { 2 - 5 } \multicolumn{1}{c|}{} & Never & Rarely & Often & $\begin{array}{c}\text { Quite } \\
\text { often }\end{array}$ & $\begin{array}{c}\text { Very } \\
\text { often }\end{array}$ \\
\hline $\begin{array}{l}\text { When using WWW search engines, how often do } \\
\text { you find relevant results? }\end{array}$ & & & & & \\
\hline $\begin{array}{l}\text { When searching electronic journals/database, } \\
\text { how often do you find relevant results? }\end{array}$ & & & & & \\
\hline $\begin{array}{l}\text { Finding relevant results took me much more time } \\
\text { than I originally expected }\end{array}$ & & & & & \\
\hline Finding relevant results is owed to good luck & & & & & \\
\hline $\begin{array}{l}\text { Finding relevant results is owed to right electronic } \\
\text { resources' choices }\end{array}$ & & & & & \\
\hline $\begin{array}{l}\text { Finding relevant results is owed to right choices of } \\
\text { research strategy/ search techniques }\end{array}$ & & & & & \\
\hline $\begin{array}{l}\text { Finding relevant results is owed to right selection } \\
\text { of keywords }\end{array}$ & & & & & \\
\hline
\end{tabular}

Thank you very much for your time!

\section{References}

Amiel, Tel, \& Sargent, Stephanie Lee (2004). Individual differences in Internet usage motives. Computers in Human Behavior, 20(6), $711 \mathrm{e} 726$.

Aula, Anne (2005). Studying user strategies and characteristics for developing web search interfacesIn Dissertations in Interactive Technology, Vol. 3. Tampere, Finland: University of Tampere, Department of Computer Science. Retrieved April 19, 2011, from. http: //acta.uta.fi/pdf/951-44-6488-5.pdf.

Aula, Anne, Jhaveri, Natalie, \& Kaki, Mika. (2005). Information search and re-access strategies of experienced web users. Paper presented at the 14th International World Wide Web Conference (WWW 2005), Chiba, Japan, May 10e14, 2005. Retrieved July 1, 2010, from http://citeseerx.ist.psu.edu/ viewdoc/download?doiZ10.1.1.76. 7424\&repZrep1\&typeZpdf.

Banwell, Linda, \& Coulson, Linda (2004). Users and user study methodology: the jubilee project. Information Research, 9(2). Retrieved July 1, 2010, from. http://InformationR.net/ir/9-2/ paper167.html.

Barrett, Andy (2005). The information-seeking habits of graduate student researchers in the humanities. Journal of Academic Librarianship, 31(4), 324e331.
Blickle, Gerhard (1996). Personality traits, learning strategies, and performance. European Journal of Personality, 10(5), 337 e352.

Branch, Jennifer L (2003). Nontraditional undergraduates at home, work, and school: an examination of information-seeking behaviors and the impact of information literacy instruction. Research Strategies, 19(1), 3e15.

Brown, Steven P., Ganesan, Shankar, \& Challagalla, Goutam (2001). Self-efficacy as a moderator of information-seeking effectiveness. Journal of Applied Psycholog, 86(5), 1043e1051.

Brunton, Christine (2007). The effects of library user-education programmes on the information-seeking behaviour of Brisbane College of Theology Students. Journal of Religious \& Theological Information, 7(2), 55e74.

Byström, Katriina, \& Järvelin, Kalervo (1995). Task complexity affects information seeking and use. Information Processing and Management, 31(2), 191e213.

Callinan, Joanne E (2005). Information-seeking behavior of undergraduate biology students. Library Review, 54(2), 86e99.

Chen, Hsin-Liang (2009). An analysis of undergraduate students' search behaviors in an information literacy class. Journal of Web Librarianship, 3(4), 333e347.

Cosijn, Erica (2006). Relevance judgements within the context of work tasks. In I. Ruthven, P. Borlund, P. Ingwersen, N. J. Belkin, 
A. Tombros, \& P. Vakkari (Eds.), Proceedings of the 1st International Conference on information interaction in context (pp. 20e29). Copenhagen, Denmark: ACM.

Craig, Ann, \& Corrall, Sheila (2007). Making a difference? Measuring the impact of an information literacy programme for preregistration nursing students in the UK. Health Information and Libraries Journal, 24(2), $118 \mathrm{e} 127$.

Davies, Karen (2007). The information-seeking behaviour of doctors: a review of the evidence. Health Information \& Libraries Journal, 24(2), 78e94.

Dervin, Brenda (1992). From the mind's eye of the user: the sensemaking qualitative-quantitative methodology. In J. Glazier, \& R. Powell (Eds.), Qualitative research in information management (pp. 61e84). Englewood, CO: Libraries Unlimited.

Ellis, David, Cox, Deborah, \& Hall, Katherine (1993). A comparison of information-seeking patterns of researchers in the physical and social sciences. Journal of Documentation, 49(4), 356e 369.

Eshet-Alkalai, Yoram, \& Chajut, Eran (2009). Changes over time in digital literacy. CyberPsychology \& Behavior, 12(6), 713e715.

Fast, Karl V., \& Campbell, D. Grant (2004). "I still like Google": university student perceptions of searching Opacs and the Web. Proceedings of the ASIST Annual Meeting, 41, 138e146.

Fidzani, B. T. (1998). Information needs and information-seeking behaviour of graduate students at the University of Botswana. Library Review, 47(7), 329e340.

Finn, Bette, \& Johnston, Pat (2004). Index use by engineering faculty and students. Georgia Library Quarterly, 41(3), 5e15.

Ford, Nigel, Miller, David, \& Moss, Nicola (2005). Web search strategies and human individual differences: cognitive and demographic factors, Internet attitudes, and approaches. Journal of the American Society for Information Science and Technology, 56(7), 741e756.

Francis, Hannah (2005). The information-seeking behavior of social science faculty at the University of the West Indies, St. Augustine Campus. The Journal of Academic Librarianship, 31(1), 67e72.

George, Carole, Bright, Alice, Hurlbert, Terry, LinkeErika, C., St. Clair, Gloriana, \& Stein, Joan (2006). Scholarly use of information: graduate students' information seeking behavior. Information Research, 11(4). Retrieved November 8, 2009, from. http://informationr.net/ir/11-4/paper272.html.

Gosling, Samuel D., Rentfrow, Peter J., \& Swann, William B., Jr. (2003). A very brief measure of the big-five personality domains. Journal of Research in Personality, 37(6), 504e528.

Griffiths, Jillian R., \& Brophy, Peter (2005). Student searching behavior and the Web: use of academic resources and Google. Library Trends, 53(4), 539e554.

Hölscher, Christoph, \& Strube, Gerhard (2000). Web search behavior of internet experts and newbies. ComputerNetworks, 33(1e6), 337e346, Retrieved November 8, 2009, from. http:// www.iicm.edu:8000/thesis/cguetl_diss/literatur/Kapitel02/ References/Hoelscher_et_al._2000/81.html.

Haglund, Lotta, \& Olsson, Per (2008). The impact on university libraries of changes in information behavior among academic researchers: a multiple case study. The Journal of Academic Librarianship, 34(1), 52e59.

Hargittai, Eszter (2002). Second-level digital divide: differences in people's online skills. First Monday, 7(4). Retrieved July 1, 2010, from. http://firstmonday.org/htbin/cgiwrap/bin/ojs/ index.php/fm/article/view/942/864.

Hargittai, Eszter (2010). Digital Na (T) Ives? Variation in Internet skills and uses among members of the "Net generation". Sociological Inquiry, 80(1), 92e113.

Hargittai, Eszter, \& Shafer, Steven (2006). Differences in actual and perceived online skills: the role of gender. Social Science Quarterly, 87(2), 432e448.

Heinström, Jannica (2000). The impact of personality and approaches to learning on information behaviour. Information
Research, 5(3). Retrieved November 8, 2009, from. http:// informationr.net/ir/5-3/paper78.html.

Heinström, Jannica (2003). Five personality dimensions and their influence on information behavior. Information Research, 9(1). Retrieved November 8, 2009, from. http://informationr.net/ir/ 9-1/paper165.html.

Heinström, Jannica (2005). Fast surfing, broad scanning and deep diving: the influence of personality and study approach on students' information-seeking behavior. Journal of Documentation, 61(2), 228e247.

Heinström, Jannica (2006). Fast surfing for availability or deep diving into quality-motivation and information seeking among middle and high school students. Information Research, 11(4). Retrieved November 8, 2009, from. http://informationr.net/ir/ 11-4/paper265.html.

Hembrooke, Helene A., Granka, Laura A., Gay, Geraldine K., \& Liddy, Elizabeth D (2005). The effects of expertise and feedback on search term selection and subsequent learning. Journal of the American Society for Information Science and Technology, 56(8), $861 \mathrm{e} 871$.

Hemminger, Bradley M., Lu, Dihui, Vaughan, K. T. L., \& Adams, Stephanie J. (2007). Information seeking behavior of academic scientists. Journal of the American Society for Information Science and Technology, 58(14), $2205 \mathrm{e} 2225$.

Hsieh-Yee, Ingrid (1993). Effects of search experience and subject knowledge on the search tactics of novice and experienced searchers. Journal of the American Society for Information Science, 44(3), 161e174.

Jamali, Hamid R., \& Asadi, Saeid (2010). Google and the scholar: the role of Google in scientists' information-seeking behaviour. Online Information Review, 34(2), 282e294.

Jenkins, Christine, Corritore, Cynthia L., \& Wiedenbeck, Susan (2003). Patterns of information seeking on the web: a qualitative study of domain expertise and web expertise. IT \& Society, 1(3), $64 \mathrm{e} 89$.

Johnson, J., David, E., Case, Donald O., Andrews, James, Allard,

Suzanne L., \& Johnson, Nathaniel E (2006). Fields and pathways: contrasting or complementary views of information seeking.

Information Processingand Management, 42(2), 569e582. Kai-Wah Chu, Samuel, \& Law, Nancy (2008). The development of information search expertise of research students. Journal of Librarianship and Information Science, 40(3), 165e177.

Kerins, Gillian, Madden, Ronan, \& Fulton, Crystal (2004). Information seeking and students studying for professional careers: the cases of engineering and law students in Ireland. Information Research, 10(1). Retrieved November 8, 2009, from. http://informationr.net/ir/10-1/paper208.html.

Kim, Jeonghyun. (2009). Predictors of behavioral intentions in web searching. Poster presented at the 2009 American Society for Information Science and Technology Annual Meeting. Thriving on Diversity - Information Opportunities in a Pluralistic World, Vancouver, British Columbia, Canada, November 6e11 2009. Retrieved July 1, 2010, from http: / / www. asis.org/Conferences/ AM09/open-proceedings/posters/82.xml

Kim, Kyung-Sun, \& Allen, Bryce (2002). Cognitive and task influences on web searching behavior. Journal of the American Society for Information Science and Technology, 53(2), 109e119.

Korobili, Stella, Malliari, Aphrodite, \& Zapounidou, Sofia (2011). Factors that influence information seeking behavior: the case of Greek graduate students. The Journal of Academic Librarianship, 37(2), 155e 165 .

Korobili, Stella, Tilikidou, Irene, \& Delistavrou, Antonia (2006). Factors that influence the use of library resources by faculty members. Library Review, 55(2), 91e105.

Landers, Richard N., \& Lounsbury, John W (2006). An investigation of big five and narrow personality traits in relation to Internet usage. Computers in Human Behavior, 22(2), $283 \mathrm{e} 293$. 
Landry, \& Fay, Carol (2006). Work roles, tasks, and the information behavior of dentists. Journal of the American Society for Information Science and Technology, 57(14), 1896e1908.

Leckie, Gloria J., Pettigrew, Karen E., \& Sylvain, Christian (1996). modeling the information seeking of professionals: a general model derived from research on engineers, health care professionals, and lawyers. The Library Quarterly, 66(2), 161e193.

Liao, Yan, Finn, Mary, \& Lu, Jun. (2007). Information-seeking behavior of international graduate students vs. American graduate students: a user study at Virginia Tech 2005. College and Research Libraries, 68(1), 5e25.

Makani, Joyline, \& WooShue, Kelli (2006). Information seeking behaviours of business students and the development of academic digital libraries. Evidence Based Library and Information Practice, 1(4), 30e45.

Marchionini, Gary (1997). Information seeking in electronic environments. Cambridge: Cambridge University Press.

Nicholas, David, Clark, David, Rowlands, Ian, \& Jamali, Hamid R (2009). Online use and information seeking behaviour: Institutional and subject comparisons of UK researchers. Journal of Information Science, 35(6), 660e676.

Nicholas, David, Huntington, Paul, \& Jamali, Hamid R (2007). diversity in the information seeking behaviour of the virtual scholar: Institutional comparisons. The Journal of Academic Librarianship, 33(6), 629e638.

Palmer, Judith (1991). Scientists and information: II. Personal factors in information behaviour. Journal of Documentation, 47(3), 254e275.

Patitungkho, Kingkaew, \& Deshpande, Neela J (2005). Information seeking behavior of faculty members of Rajabhat Universities in Bangkok. Webology, 2(4). Retrieved November 8, 2009, from. http: //www.webology.ir/2005/v2n4/a20.html.

Ren, Wen-Hua (2000). Library instruction and college student selfefficacy in electronic information searching. The Journal of Academic Librarianship, 26(5), 323e328.

Rieger, Oya $Y$ (2009). Search engine use behavior of students and faculty: user perceptions and implications for future research. First Monday, 14(12). Retrieved July 1, 2010, from. http:// firstmonday.org/htbin/cgiwrap/bin/ojs/index.php/fm/article/ viewArticle/2716/2385.

Rowlands, Ian, \& Nicholas, David (2008). Understanding information behavior: how do students and faculty find books? The Journal of Academic Librarianship, 34(1), 3e15.

Sadler, Elizabeth (Bess), \& Given, Lisa M (2007). Affordance theory: a framework for graduate students' information behavior. Journal of Documentation, 63(1), 115e141.

Samson, Sue (2010). Information literacy learning outcomes and student success. The Journal of Academic Librarianship, 36(3), $202 \mathrm{e} 210$.

Sharifabadi, Saeed Rezaei. (1996). Information seeking and communication among researchers and the impact of electronic networks: a literature review (Unpublished PhD thesis). In Effects of the Internet on research activities, information seeking and communication behaviour of Australian academic psychologists (Chapter 3, pp. 45e86). Sydney: University of New South Wales. Retrieved April 19, 2011, from http://www. alzahra.ac.ir/rezaei/PDF/CHAP3.pdf.

Talja, Sanna, \& Maula, Hanni (2003). Reasons for the use and nonuse of electronic journals and databases. Journal of Documentation, 59(6), 673e691.

Tella, Adeyinka (2009). Correlates of undergraduates' informationseeking behavior. College \& Undergraduate Libraries, 16(1), 1e19. Thatcher, Andrew (2008). Web search strategies: the influence of web experience and task type. Information Processing \& Management, 44(3), 1308e1329.
Tramullas, Jesús, \& Casabon, Ana Sanchez. (2010). Scientific information retrieval behavior: A case study in students of philosophy. Paper presented at the I Congreso Español de Recuperación de Información (CERI 2010), Madrid, Spain, 15e16 June 2010. Retrieved July 1, 2010, from http://ir.ii.uam.es/ ceri2010/papers/ceri2010-tramullas.pdf.

Tsai, Meng-Jung (2009). Online Information Searching Strategy Inventory (OISSI): a quick version and a complete version. Computers \& Education, 53(2), 473e483.

Tsai, Meng-Jung, \& Tsai, Chin-Chung (2003). information searching strategies in web-based science learning: the role of Internet self-efficacy. Innovations in Education and Teaching International, 40(1), 43e50.

Urquhart, Christine, \& Rowley, Jennifer (2007). Understanding student information behavior in relation to electronic information services: Lessons from longitudinal monitoring and evaluation, Part 2. Journal of the American Society for Information Science and Technology, 58(8), 1188e1197.

Urquhart, Christine, Thomas, Rhina, Spink, Sian, Fenton, Roger, Yeoman, Alison, Lonsdale, Ray, et al. (2005). Student use of electronic information services in further education. International Journal of Information Management, 25(4), 347e362.

Vakkari, Pertti (1999). Task complexity, problem structure and information actions integrating studies on information seeking and retrieval. Information Processing and Management, 35(6), $819 \mathrm{e} 837$.

Vezzosi, Monica (2009). Doctoral students' information behavioran exploratory study at the University of Parma (Italy). New Library World, 110(1e2), 65e80.

Waldman, Micaela (2003). Freshmen's use of library electronic resources and self-efficacy. Information Research, 8(2). Retrieved July 1, 2010, from. http://informationr.net/ir/8-2/ paper150.html.

Weiler, Angela (2005). Information-seeking behavior in Generation $Y$ students: motivation, critical thinking, and learning theory. The Journal of Academic Librarianship, 31(1), 46e53.

White, Ryen W., Dumais, Susan T., \& Teevan, Jaime. (2009). Characterizing the influence of domain expertise on web search behavior. Paper presented at the 2nd ACM international Conference on web Search and data mining (WSDM'09), Barcelona, Spain, February 9-12, 2009. Retrieved April 19, 2011, from www.wsdm2009.org/papers/p132-white.pdf.

Whitmire, Ethelene (2002). Disciplinary differences and undergraduates' information-seeking behavior. Journal of the American Society for Information Science and Technology, 53(8), $631 \mathrm{e} 638$.

Wildemuth, Barbara M (2004). The effects of domain knowledge on search tactic formulation. Journal of the American Society for Information Science and Technology, 55(3), 246e258.

Williamson, Kirsty, Bernath, Vivienne, Wright, Steven, \& Sullivan, Jen (2008). Research students in the Electronic Age: Impacts of changing information behavior on information literacy needs. Communications in Information Literacy, 1(2). Retrieved July 1, 2010, from. http://www.comminfolit.org/ index.php/cil/article/view/Fall2007AR1/48.

Wilson, T. D. (1981). On user studies and information needs. Journal of Documentation, 37(1), 3e15.

Wilson, T. D. (2006). on user studies and information needs. Journal of Documentation, 62(6), 658e670.

Zhang, Xiangmin, Anghelescu, Hermina G. B., \& Yuan, Xiaojun (2005). Domain knowledge, search behavior, and search effectiveness of engineering and science students: an exploratory study. Information Research, 10(2). Retrieved July 1, 2010, from. http://InformationR.net/ir/10-2/paper217.html. 